\title{
Extracting rents through foreclosures: The rescue of Catalunya Banc as a new urban strategy following the burst of the Spanish bubble
}

Abstract

Using the paradigmatic example of Catalunya Banc, this paper analyses the Spanish varieties of the new financial engineering used to appropriate urban rent by home dispossession. It aims to contribute to the study of the new forms of financialization that have appeared since 2008. Particular attention is given to the role of the state, the emergence of private equity funds as global real estate owners and how this has translated into a wave of evictions due to mortgage foreclosures. In short, this article highlights the implications of the uneven development resulting from the exhaustion of the so-called Spanish model of accumulation during the real estate boom years.

Keywords

Financialization $\cdot$ bank bailout $\cdot$ housing policy $\cdot$ foreclosures $\cdot$ home dispossession - Spain

(C) University of Warsaw - Faculty of Geography and Regional Studies

\author{
Sònia Vives-Miró' \\ Aaron Gutiérrez ${ }^{2}$ \\ 'Department of Geography, \\ University of Santiago de Compostela, Spain \\ e-mail:so.vives@gmail.com \\ ${ }^{2}$ Department of Geography, \\ Rovira i Virgili University, Spain \\ e-mail: aaron.gutierrez@urv.cat \\ Received: 15 July 2017 \\ Accepted: 19 October 2017
}

Introduction: Spain Within the Context of the European Crisis

In the context of the Eurozone crisis and under the pretext of ensuring Europe's financial stability and preventing its collapse, a number of measures were introduced to recapitalize the banks and control national debt. These included the socialization of bank losses and policies of austerity (Lapavitsas 2012). The most significant policies applied in the Eurozone during this period began with the creation of the European Fund for Financial Stability early in 2010. This was a rescue package of 750 billion euros (FROB 2015). The Pact of the Euro, ratified in June 2011, consisted of a series of political reforms aimed at consolidating the financial stability and competitiveness of the EU member states. This forced them to increase the application of austerity measures in order to reduce their deficits and levels of national debt (Badenes 2015) and was the starting point for the austerity policies of the Eurozone that were subsequently consolidated in March 2012 with the signing of the Treaty on Stability, Coordination and Governance of the Economic Monetary Union (better known as the Fiscal Compact). This agreement led to the introduction of the Golden Rule, which envisaged economic penalties for failure to maintain balanced budgets and limit the level of national debt. ${ }^{1}$

Spain's road to ruin was built on the circulation of large sums of surplus capital, which resulted in the creation of the real estate bubble. This fuelled spiralling prices that ended up

\footnotetext{
${ }^{1}$ In compliance with this rule, in December 2011, the Spanish parliament passed a modification of the Constitution that limited the state's structural deficit to $0.4 \%$ from 2020 onwards. Furthermore, repaying debt became the highest priority for public spending: "Credits to pay the interest and capital on the public debt of the Administrations shall always be included as expenses in the state's budgets and its payment shall be regarded as an absolute priority. These credits shall not be subject to any amendments or modifications and must comply with the conditions laid down in the Law governing their issue" (Spanish Constitution, Article 135.3).
}

mobilizing middle-class investments and drew in foreign capital; in both cases, this was for the direct acquisition of real estate through investment funds (Sevilla-Buitrago 2015, p. 38). In this sense, the Spanish model (López \& Rodríguez 2011) has been based on the continuous revaluing of real estate and on the demand for owner-occupied housing based on widespread indebtedness (Gutiérrez \& Delclòs 2016; Gutiérrez \& Domènech 2017a). In other words, during the years of the real estate boom, the Spanish model of accumulation was based mainly on the financialization of the built environment (Aalbers 2008; Rutland 2010) via specialization in the secondary capital circuit and an extension of the practice of savings banks providing cheap credit (Coq-Huelva 2013). This model of accumulation had its origins in housing policies promoted during the Francoist period and became fully consolidated when Spain joined the EU in the 1980s. The main state policies that have supported this model are the liberalization of the mortgage market and the expansion of securitization since 1992; the liberalization of the land market from 1994 onward, which removed the majority of the restraints that urban planning had placed on urbanization; and a housing policy based on reducing the supply of public housing, the marginalization of the market for rented housing, and fiscal discounts for the purchase of housing (López \& Rodríguez 2011). These measures were accompanied by a rescaling of the state and a series of strong networks of power, including investors, local politicians and savings banks. Within this model, which produced what has been referred to as the "Spanish miracle," the key players were the financial institutions. The banks financed the purchase of land and construction for promoters and the acquisition of housing for buyers, thanks to their especially low interest rates (García-Montalvo 2008; López \& Rodríguez 2010, 2013).

The end of the Spanish model became evident with the bursting of the real estate bubble and the crisis of 2008. The great 
expansion of credit by European domestic economies (the value of mortgage debt multiplied by a factor of twelve in the period 1995-2007, rising from 24 billion to 300 billion euros, at today's prices) (López \& Rodríguez 2010, p. 190) led to a rapid increase in the number of evictions from 2009 onward. According to data from the Consejo General del Poder Judicial (General Legal Council), the period 2007-2014 saw over 600,000 foreclosures. Unofficial estimates by the Plataforma de Afectados por la Hipoteca (PAH - Platform for Mortgage Victims) have set the total number of foreclosures resulting in evictions and the loss of first residences at above 260,000 .

Under the pretext of the crisis, the rescue of Spanish banks by the EU has involved the gradual transfer of the debt problem from the public to the private sector. This process ensured the repayment of money lent to Europe's banks but also consolidated a scenario of increasing social exclusion and vulnerability in Spanish society. In short, this situation offered the ideal excuse to unfurl an unprecedented process of neoliberalization under the name of austerity (Sevilla-Buitrago 2015, p. 42).

Within this context, the main objective of this article is to analyse the new financial and real-estate strategies undertaken in Spain from 2008 onwards and their translation into a wave of evictions due to mortgage foreclosures. To achieve this research objective, this article analyses these processes with specific reference to the case of Catalunya Banc. This financial institution provides a paradigmatic case study: its rescue has implied the active involvement of state institutions and resulted in the development of mechanisms for carrying out accumulation by dispossession (Harvey 2003). Moreover, throughout the processes of rescue and nationalization, this bank has remained at the forefront of the sector in terms of the number of foreclosures it has carried out in Spain (Gutiérrez \& Delclòs 2017). Briefly stated, this article seeks to highlight the implications, in the form of uneven development (Smith 1984 [2010]), of these new strategies, which often remain hidden beneath the hegemonic discourse of orthodox economics. Along these lines, we shall start by presenting a review of the real estate and financial policies undertaken in Spain since 2008 (section 2). We shall then study the mechanisms used to rescue and restructure the savings bank, Catalunya Caixa, and to convert it to a new bank (section 3.1). Third, we will analyse the uneven spatial pattern of evictions related to foreclosures, using this as evidence of their impact in urban areas (section 3.2). Finally, we shall consider the conclusions that this research could contribute to the study of new scenarios for urban financialization since 2008 .

\section{Real estate and financial policies in Spain since 2008}

Since 2008, the policies of the Spanish state have been aimed at maintaining the financial and real estate sectors as the main engines of accumulation for the national economy. These policies have been structured around new forms of financial engineering within the context of austerity imposed by the European Union. This has been particularly evident since the signing of the Memorandum of Understanding (MoU) in 2012.

During the last bullish cycle, the financial sector played a fundamental role in the specialization that took place in the secondary circuit of accumulation of the Spanish model (López \& Rodríguez 2010). In fact, it is important to stress that the Spanish financial sector, immersed in the paradigm of financialization, not only worked as a financing channel for commuting capital from one accumulation circuit to another but also as an accumulation sector in itself (Aalbers 2008). Before the crisis broke out, the financial sector was basically structured around private banks and savings banks. The savings banks had an extensive regional presence and stood out for their links to real estate businesses.

When the financial and economic crisis began in 2008, the economic unsustainability of this accumulation model became evident (particularly in the case of the regional savings banks). Official data provided by the Bank of Spain shows that the bank bailout received a total capital injection of 61 billion euros through public funding (Banco de España, 2014). To this amount, it is necessary to add another type of aid that is not technically considered public spending, with which the value of support would reach almost 108 billion euros, according to data from Spain's Tribunal de Cuentas (Court of Auditors) (BOE 10/08/2014). However, the total volume of public money that has been either directly or indirectly injected into the financial sector amounts to 1.4 trillion euros (Plataforma Auditoría Ciudadana de la Deuda 2013; Sánchez Mato 2013). This aid has been provided through different state institutions ${ }^{2}$ and channelled via the creation of other public and "private" entities. ${ }^{3}$ It has materialized through two different types of instruments: capitalization measures ${ }^{4}$ (direct injections of capital, the conversion of convertible preferred stocks into capital and asset protection schemes) and liquidity measures $^{5}$ (the acquisition of assets, warranties and guarantees, credits obtained under advantageous conditions and convertible preferred stocks) (Sánchez Mato 2013).

The bank rescue was therefore carried out via two different lines of action: sanitizing and bankarization. The first step toward the so-called sanitizing of the financial institutions was the creation of the SAREB (the "bad bank"). This was done in November 2012 as part of the MoU agreement. It involved 55\% private and $45 \%$ public capital, and its aim was "to help to sanitize the financial sector and, more specifically, those institutions that were beset with problems as a result of their excessive exposure to the real estate sector, with the aim of reducing their exposure to risk and to liquidate problematic assets in an orderly manner" (SAREB 2012). This was followed by the transfer of toxic assets to either the SAREB or to investment funds through the sale of their real estate portfolios. The contribution of public funds was carried out via the FROB and totalled 2.2 billion euros.

The second action included in this sanitizing process was the sale of real estate portfolios to private equity funds. These portfolios were sold at prices that bore little relation to the market price. Furthermore, they were sold with an opaqueness that prevented the right of withdrawal of the mortgage owners (Vives-Miró 2015). Thus, once more, the business of private equity funds was both subsidized and promoted. Both of these actions, the transfer of assets to the SAREB and the sale of real estate portfolios, have implied the socialization of the losses of the real estate business of the savings banks and the conversion of private into public debt (Gutiérrez \& Domènech 2017b).

${ }^{2}$ The aid has been awarded to the financial institutions by the state via loans granted to credit agencies by the European Central Bank under advantageous conditions and to the state by the European Commission, the European Central Bank and the International Monetary Fund.

${ }^{3} \mathrm{New}$ bodies such as the Fondo de Adquisición de Activos Financieros (FAAF - Fund for the Acquisition of Financial Assets), the Fondo de Reestructuración Ordenada Bancaria (FROB - Fund for Orderly Bank Restructuring) and the Sociedad de Gestión de Activos Procedentes de la Reestructuración Bancaria (SAREB - Company for the Management of Assets proceeding from the Restructuring of the Banking System), and others that already existed including the Instituto de Crédito Oficial (ICO - Institute of Official Credit), the Secretaría General del Tesoro y Política Financiera (General Secretariat for the Treasury and Financial Policy), and the Fondo de Garantías de Depósitos de Entidades de Crédito (FGD - Guarantee Fund for Bank Deposits).

${ }^{4}$ Capitalization measures are those used to attempt to solve problems of solvency suffered by financial institutions and to strengthen their capital. In other words, they help to bolster their resources in order to allow them to meet their payment obligations when all of their resources are insufficient to pay the total amount that they owe (Sánchez Mato 2013)

${ }^{5}$ Liquidity measures are those that seek to give financial institutions sufficient liquid resources to meet their payment obligations. In this case, it is presumed that the banks and savings banks have sufficient resources to pay their debts, not necessarily in the form of liquid assets, but rather in properties, shares, and other types of financial investments (Sánchez Mato 2013). 


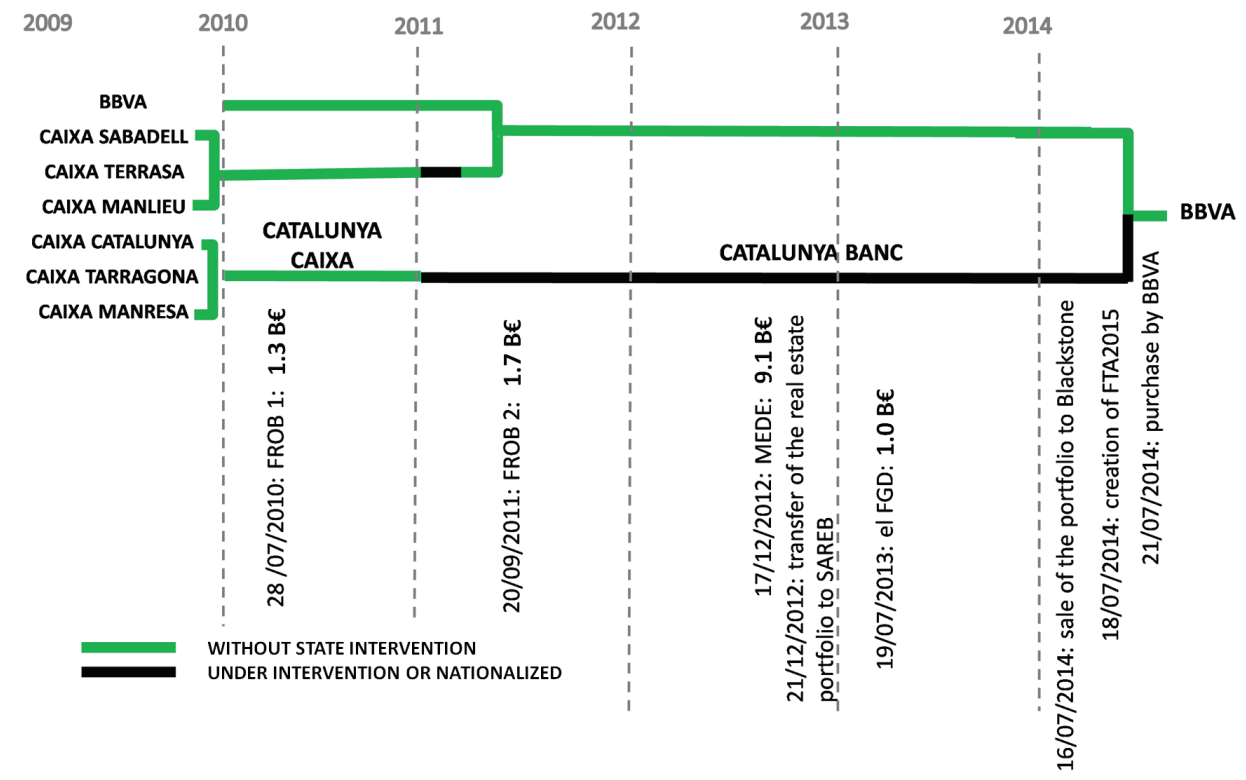

Figure 1. The evolution of the process of restructuring Catalunya Banc Source: own elaboration

At the same time that this sanitizing process was being conducted, the savings banks were bankarized. The first strategy employed involved aggregating the different financial institutions into SIP (Institutional Protection Systems) through what were known as "cold fusions", with the institutions maintaining their legal identities and obtaining public funds in the process. A second step within this process was the nationalization of banks with the support of funding provided by the FROB. A new bankingsystem scheme emerged from this process in which the number of entities was reduced to less than a quarter of the original number, with the effective disappearance of almost all of the original savings banks. Through this process of bankarization of the savings banks, by which the financing sector received further subsidies, more private debt was converted into public debt, and the financial sector became even more concentrated.

Accumulation of urban rents through evictions by Catalunya Banc

New financial mechanisms for the appropriation of financial and real estate rent: The state, Catalunya Banc and Blackstone

The creation of Catalunya Banc provides an excellent example of the bankarization of the regional savings banks (see Figure 1). It began after the creation of the FROB in June 2009 and the coming into force of Royal Decree Law 11/2010 relating to the governing bodies of savings banks and other aspects of their legal regimes.

The restructuring process began with the merger of Caixa Catalunya, Caixa Tarragona and Caixa Manresa to create Catalunya Caixa (1 July 2010) and concluded with the creation of the new bank (Catalunya Banc) on 7 June 2011 (Rodríguez García 2013). It implied the receipt of initial aid totalling 1.3 billion euros on 28 July 2010; this came in the form of convertible preferred stocks. This was received on condition of the bankarization and recapitalization of the group through private investment entering its capital before 30 September 2011, as stipulated in Decree Law Ley 2/201117 (Europa Press 2010). However, at the end of the stipulated period, Catalunya Caixa still had not managed to attract the agreed amount of private investment. As a result, the FROB intervened once more to the tune of 1.7 billion euros (FROB 2011). In this way, the FROB acquired $89.74 \%$ of the bank's shares. From this moment onward, therefore, we can talk about a process of "nationalization".

Then, on 20 July 2012, the Memorandum of Understanding (MoU) was signed. As a result of these agreements, in December 2012 the FROB acquired all the shares in Catalunya Banc for a token price of 1 euro. This happened after the 1.3 billion euros in preferred stocks in Catalunya Caixa, subscribed in 2010, had been converted into shares. Such agreements meant that Catalunya Banc received 9.1 billion euros from the ESM and the original savings bank ceased to participate in the shareholding of the new Catalunya Banc (Lne 2012). After that, the FROB had until the end of 2016 to proceed with the process of disinvestment in the bank. In other words, it was given four years to privatize the former nationalized bank; failing that, it would have been liquidated (El Mundo 2013).

In addition to this bankarization, Catalunya Caixa had to submit to a process of sanitization. Thus, on 21 December, Catalunya Caixa transferred its property portfolio to the SAREB. In total, this implied the transfer of 37,000 assets; 27,000 of these proceeded directly from Catalunya Caixa, while the other 10,000 were related to credits held by the real estate developer. Taken together, this operation had a total value of 6.7 billion euros (El País 2012).

Continuing with the process of sanitization, on 16 July 2014, the toxic mortgage portfolio of Catalunya Banc was acquired by the Blackstone-TPG investment fund. The portfolio had a nominal value of 6.4 billion and provisions of 2.2 billion euros. This fund, which specializes in the acquisition of financial assets with problems, obtained a discount of approximately $40 \%$ with respect to the total value of the portfolio. In this process, it is important to highlight that, in order to promote the sale operation, the toxic asset portfolio was transferred to the FTA 2015 Securitization Fund for its book value of 4.2 billion euros. The FTA 2015 included participation by Blackstone, with a contribution of 3.6 billion euros, and also by the FROB, with the remaining 0.6 billion euros (El Mundo 2014). This Securitization Fund issues debt of two types, senior and junior, which are acquired by Blackstone and the FROB. The FROB keeps the portion supported by the lower-quality (junior) mortgages and is directly affected by any potential defaults. In contrast, the senior bonds, which offer greater security, are backed by Blackstone. 
MISCELLANEA GEOGRAPHICA - REGIONAL STUDIES ON DEVELOPMENT

It is important to underline here that $59 \%$ of these mortgages have suffered some type of default (El País 2014; El Mundo 2014). In the case of the portfolio becoming profitable in the future, the FROB and Blackstone would share any additional yields on an equal basis (El País 2014).

With this new contribution of public capital, the cost of the rescue for this banking group increased to 12.6 billion euros (El Mundo 2014). This new financial architecture has implied a new movement of capital through the creation of liquidity based on a spatial fix (Gotham 2009) - in this case, a toxic spatial fix. This has constituted another step in the financialization of the built environment (Aalbers 2008; Christophers 2011).

Via this type of financialization, families holding mortgages obtained from Catalunya Banc have seen "the rights relating to their mortgage credit ceded to the FTA 2015". Spanish legislation does not allow Catalunya Banc to sell the ownership of its mortgages. For this reason, it must continue to administer them, even though the debt now belongs to the FTA. However, Catalunya Banc has subcontracted its management to Anticipa Real Estate. This real estate company, a subsidiary of the bank, has also been purchased by Blackstone. In other words, Catalunya Banc is the nominal owner of the mortgages, but Blackstone owns the debt and is also the owner of the company contracted to administer the mortgages. From now on, families with mortgages must, therefore, negotiate with the vulture fund (El Diario 2015).

The operation with Blackstone, therefore, definitively opened the door to the privatization of the bank. Finally, on 21 July 2014, the FROB sold Catalunya Banc to BBVA for over 1.2 billion euros; this was less than the 2.6 billion-euro net value of Catalunya Banc (EI País 21/07/2014). In addition to selling for a lower price than the value of its assets, the FROB lost 0.5 billion euros in additional guarantees offered to BBVA for the purchase of Catalunya Banc. These guarantees have been destined to cover contingencies deriving from the sale of hybrid products (preferred stocks and subordinated debt), mortgage "floor clauses"6 and "swaps", and an eventual suspension of the bank insurance agreement with Mapfre (valued at 140 million euros) (Europa Press 2014).

In short, the rescue of Catalunya Banc has cost 14 billion euros in public money, according to official sources (El Diario 2013). This amount is similar to the value of the cuts made in health and education since 2013 (13.8 billion euros). However, this data contrasts with the information presented by Sánchez Mato (2013), according to whom the rescue of this bank cost 44.9 billion euros. In addition to the aid described in this text, Sánchez Mato also considered, among other measures, issues of debt guaranteed by the Spanish General Secretariat of the Treasury and Financial Policy (10.6 billion euros) and financing received from the BCE (14.2 billion euros). These amounts are reflected in Table 1.

Foreclosures of Catalunya Banc fuel uneven development

This section examines the other side of the coin in the operation to rescue Spain's banks: the exacerbation of social vulnerability associated with the housing crisis. To do so, it is necessary to analyse the spatial distribution pattern of Catalunya Banc foreclosures and their contribution to the precarization of the most deprived urban areas and neighbourhoods. The analysis is based on the Catalonia region, where Catalunya Banc concentrates most of its activities and real estate assets. The data used in the study was obtained from the registry of empty housing units owned by banks, which was created by the Catalan Housing Agency and updated in March 2016. This data refers to housing units that, following a mortgage foreclosure process and after the residents (and owners) have been evicted, are now

${ }^{6}$ These clauses, which are not included by all banks, set a "floor" - or minimum interest rate - that clients have to pay to the bank, even if the benchmark rate - normally the Euribor - drops below this level.
Table 1. Summary of public aid to Catalunya Banc

\begin{tabular}{|c|c|c|}
\hline & $\begin{array}{l}\text { TOTAL } \\
\text { (B€) }\end{array}$ & $\begin{array}{l}\text { Catalunya } \\
\text { Banc }(\mathrm{B} \epsilon)\end{array}$ \\
\hline Capital & 59.1 & 12.1 \\
\hline Asset Protection Scheme & 28.2 & \\
\hline Subtotal of capitalization measures & 87.4 & \\
\hline $\begin{array}{l}\text { State Guarantees through the } \\
\text { emission of banking debt }\end{array}$ & 64.1 & 10.6 \\
\hline Lines of liquidity & 3.1 & 1.2 \\
\hline $\begin{array}{l}\text { Implicit State Guarantee for banking } \\
\text { deposits }\end{array}$ & 792.3 & \\
\hline Convertible preferred stocks & 2.0 & \\
\hline Acquisition of SAREB assets & 50.8 & 6.7 \\
\hline $\begin{array}{c}\text { Loans from the European Central } \\
\text { Bank }\end{array}$ & 357.3 & 14.2 \\
\hline Subtotal of financial measures & $1,269.6$ & \\
\hline Total risk contingency & $1,356.9$ & 44.7 \\
\hline
\end{tabular}

Source: Based on Sánchez Mato, 2013

empty and in the hands of the banks waiting for a new profit. According to this data, Catalunya Banc is the financial institution that holds the second-highest volume of housing units resulting from foreclosures executed in Catalonia (2,945 housing units). First place in this ranking is occupied by Bankia, and both entities have been rescued (and nationalized). This situation highlights one of the key characteristics of Spain's financial sector: those banks that have been rescued with public money are also the banks that carry out the largest number of foreclosures and evictions. In fact, almost $65 \%$ of the total number of housing units owned by banks resulting from foreclosure is concentrated in the hands of entities that have been rescued (Gutiérrez \& Delclòs 2017). This clearly demonstrates the consequences of the expansive policies that these banks pursued during the property boom years. Both Catalunya Banc and Bankia pursued aggressive commercial policies for the promotion of mortgage credits, resulting in the highest quotas of credits with a considerable risk of default (Ruiz et al. 2016). This meant that they were destined to become the main protagonists of the real estate crisis in Catalonia.

Figure 2 shows the distribution of the volume of housing units held by Catalunya Banc in Catalonia via mortgage foreclosure processes by municipality. The first map shows their distribution in absolute terms. As we might expect, this largely corresponds to the demographic size of the various cities. In other words, the greatest numbers of used housing units are located in the most populated urban areas. The first position is occupied by the municipality of Barcelona; this is followed by Catalonia's intermediate cities (Sabadell, Terrassa, Lleida, Mataró, Tarragona, Reus, Manresa, etc.) (Gutiérrez \& Domènech 2017a). However, if we utilize a map showing the distribution of used housing units held by Catalunya Banc per 1,000 inhabitants as our reference, it is possible to observe two very clear territorial patterns. First, the particular effects of this phenomenon on the metropolitan area of Barcelona can be seen. Along these lines, Gutierrez and Delclòs (2015) have shown how, during the decade of the property boom, small- and medium-sized towns (with 5,000-20,000 inhabitants) tended to concentrate the highest ratios of housing production in Catalonia. Among these municipalities, the ones that have 

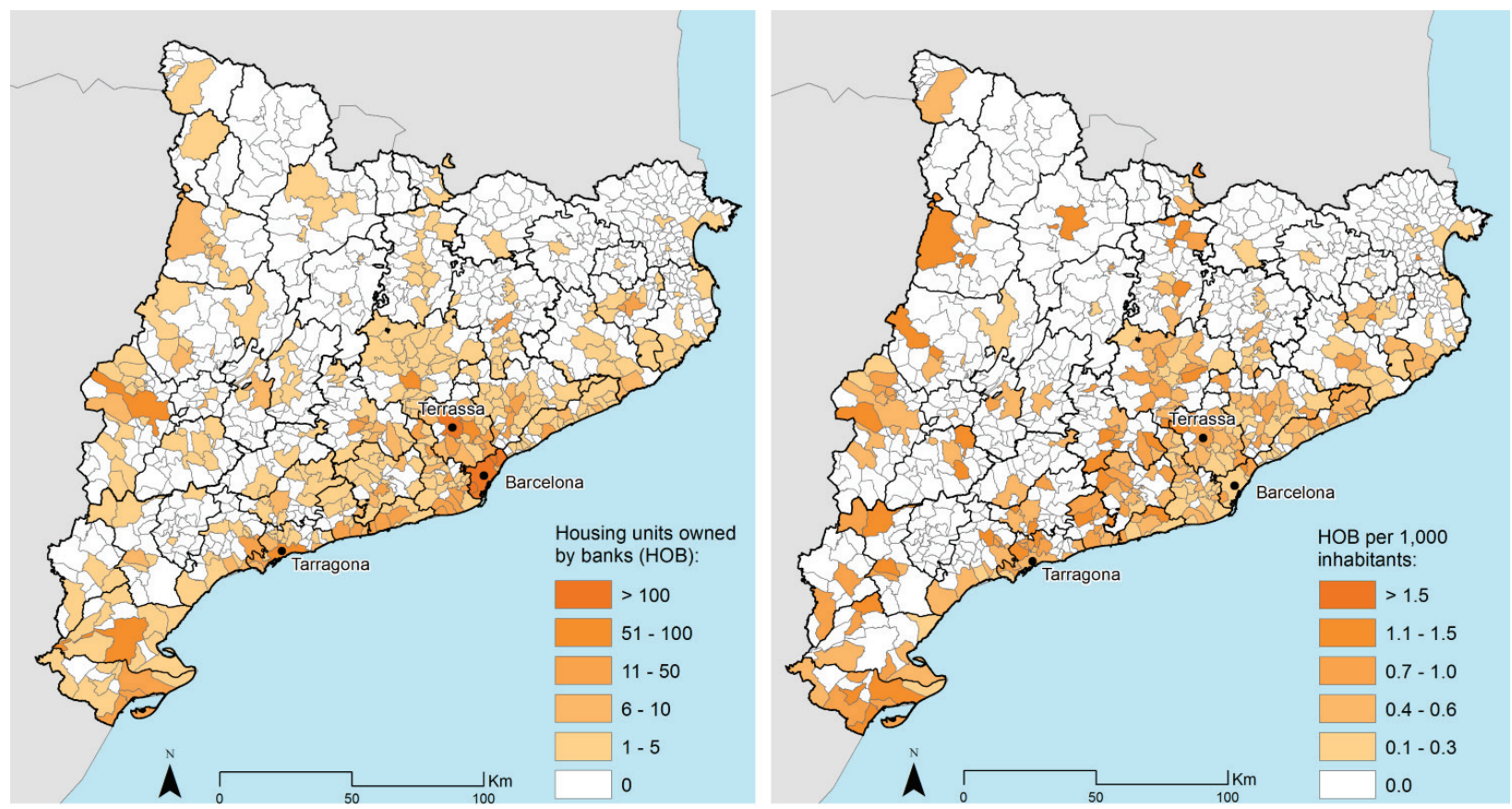

Figure 2. Distribution of used housing units held by Catalunya Banc, by municipality Source: Own elaboration based on the registry of vacant housing units owned by banks in Catalonia

concentrated the greatest volume of housing production have been those located within the metropolitan region of Barcelona and along the Mediterranean Coast. Later, after the real estate bubble burst, these municipalities also suffered the main consequences of the shrinking of the property market: the highest ratios of unoccupied housing, unfinished residential buildings, and housing units held by banks (Gutierrez \& Delclòs 2015, 2017). Figure 2 demonstrates how Catalunya Banc has been one of the main entities involved in this process. The second characteristic that can be observed from Figure 2 is the concentration of housing units held by Catalunya Banc in the areas of influence of the two smallest savings banks that were integrated into this new bank. This can be observed in the province of Tarragona (Caixa de Tarragona, in the south of Catalonia) and in the comarca (local district or county) of Bages (Caixa de Manresa, in the central area of Catalonia). This has allowed us to illustrate the consequences of the policies of intense mortgage credit capture undertaken by their respective office networks during the years of the real estate bubble.

The cases of the cities of Tarragona and Terrassa (see Figure 3) were used to demonstrate, at the neighbourhood level, how foreclosures of Catalunya Banc have been fuelling uneven development. Both cities present interesting cases. Terrassa is one of the main cities in the metropolitan region of Barcelona (with a population of 215,000 ). From the onset of the Spanish mortgage crisis, it has been one of the cities with the highest ratios of evictions due to foreclosures. Tarragona (140,000 inhabitants) is the capital of the second-largest urban region in Catalonia after Barcelona. In this case, the interest lies in its condition of being the headquarters of one of the three savings banks (Caixa Tarragona) that would form Catalunya Caixa following a process of fusion. As a result, this bank has an important presence in the city.

Figures 4 and 5 demonstrate the uneven distribution of housing stock owned by Catalunya Banc (the orange points) and the rest of the banks (the white points) in Tarragona and Terrassa, and their clear tendency to concentrate in certain specific areas. The maps also show the levels and distribution of unemployment and the percentage of immigrant population by census tract (in both cases according to data from the 2011 census).

There is a vast literature on the residential segregation of immigrant populations in Spanish cities and the overall tendency towards their concentration in the most deprived neighbourhoods (in Catalan context: Bayona 2007; Bayona \& López-Gay 2011; Martori \& Hoberg 2008; Pujol-Perdices \& Gutiérrez 2017). Nowadays, according to our findings, it could be emphasized that in Tarragona and Terrassa these neighbourhoods have also suffered a more intensive process of home dispossession. From the maps, it is possible to observe that the higher the unemployment rate and the greater the density of the immigrant population, the larger the number of used housing units held by banks in a given area. The increase in the number of this type of housing unit per thousand inhabitants, the level of unemployment, and the percentage of immigrant population in each census tract (87 in Tarragona and 143 in Terrassa) give a minimum Pearson correlation coefficient of 0.58 for Tarragona and a maximum of 0.75 for Terrassa (both of which were statistically significant at the $99.9 \%$ confidence level). Previous studies have also underlined the spatial correlation of these variables in both cities (Gutiérrez \& Delclòs 2016). Moreover, this correlation between social vulnerability and the concentration of housing units in the hands of banks has been highlighted in other Catalan and Spanish cities (Gutiérrez \& Domènech 2017a, 2017b). In Tarragona, it is relevant to stress their presence in Bonavista, Campclar and Torreforta (neighbourhoods on the west side of the city). These neighbourhoods constitute $23.1 \%$ of the housing stock of Tarragona, but concentrate $62.9 \%$ of all the housing units owned by Catalunya Banc in the city. In Terrassa, the higher concentration is observed in the deprived neighbourhoods on the east side of the city ( $\mathrm{Ca}$ n'Anglada, Égara and La Marina, among others). In this case, these areas constitute $23.4 \%$ of the housing stock of the city, but concentrate $56.4 \%$ of the housing units owned by Catalunya Caixa. In 

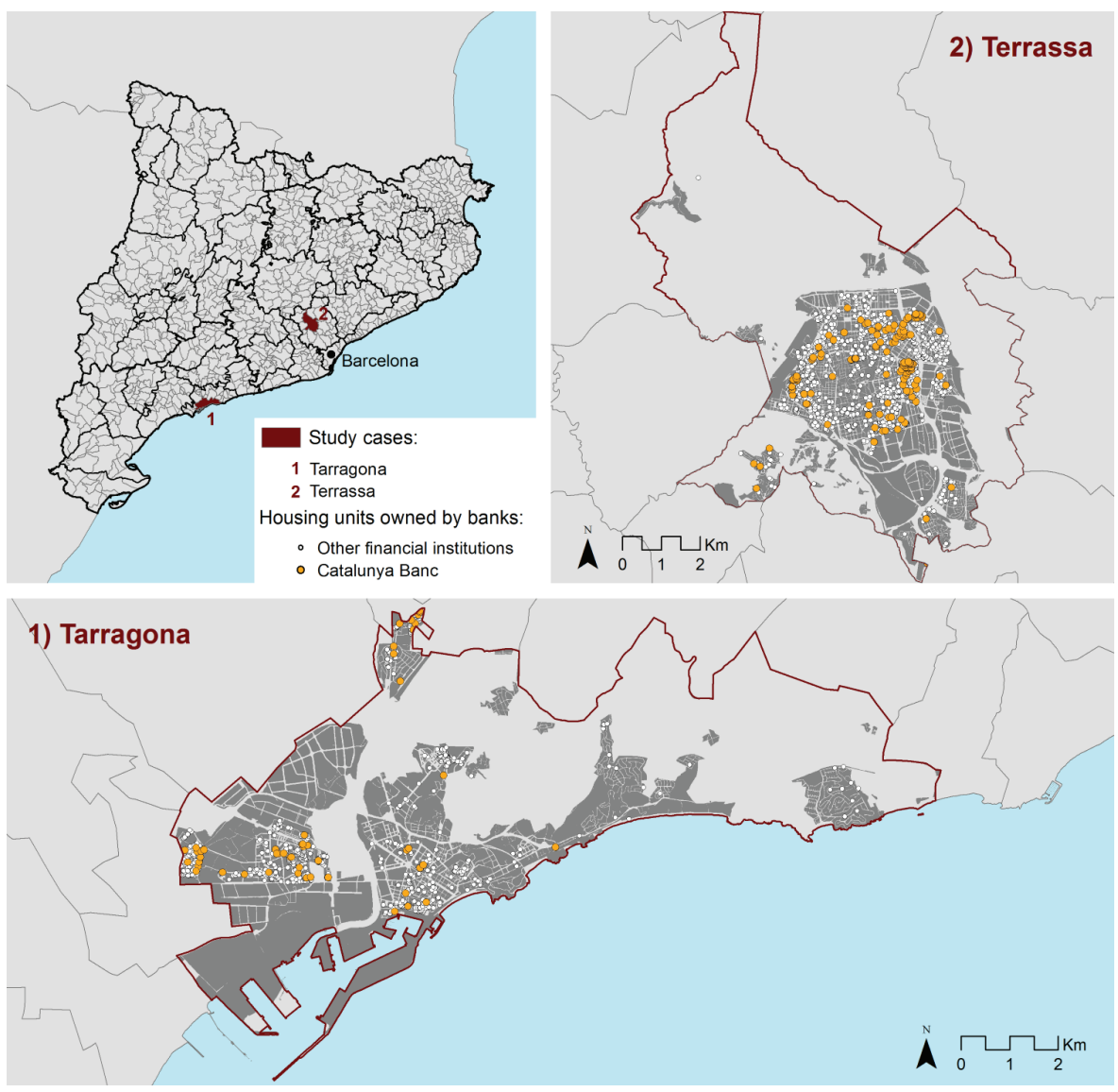

Figure 3. Locating Tarragona and Terrassa Source: Own elaboration based on the registry of vacant housing units owned by banks in Catalonia

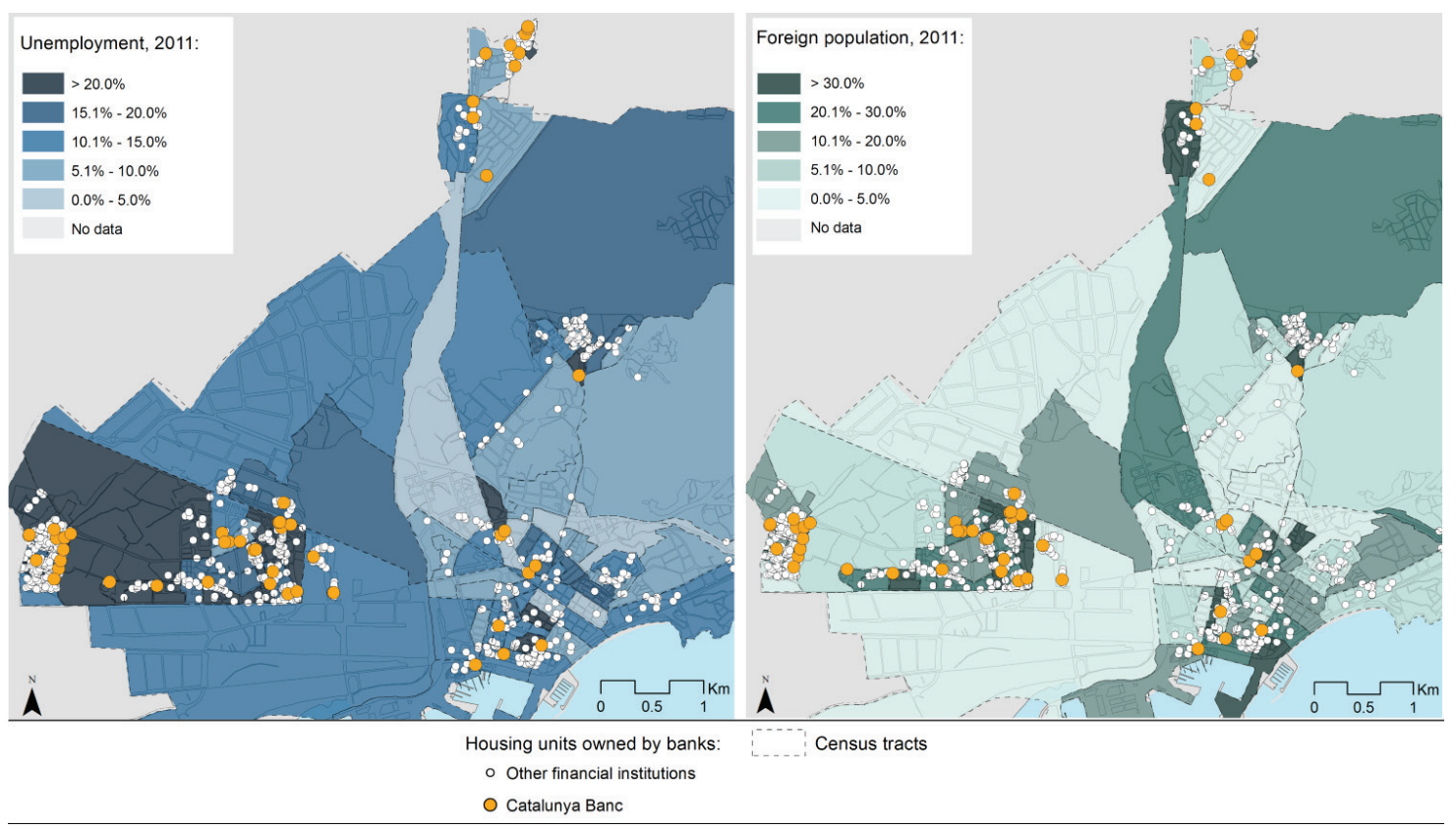

Figure 4. Housing units held by Catalunya Banc and unemployment rates (Tarragona and Terrassa) Source: Own elaboration based on data from the 2011 census and the registry of vacant housing units owned by banks in Catalonia. 


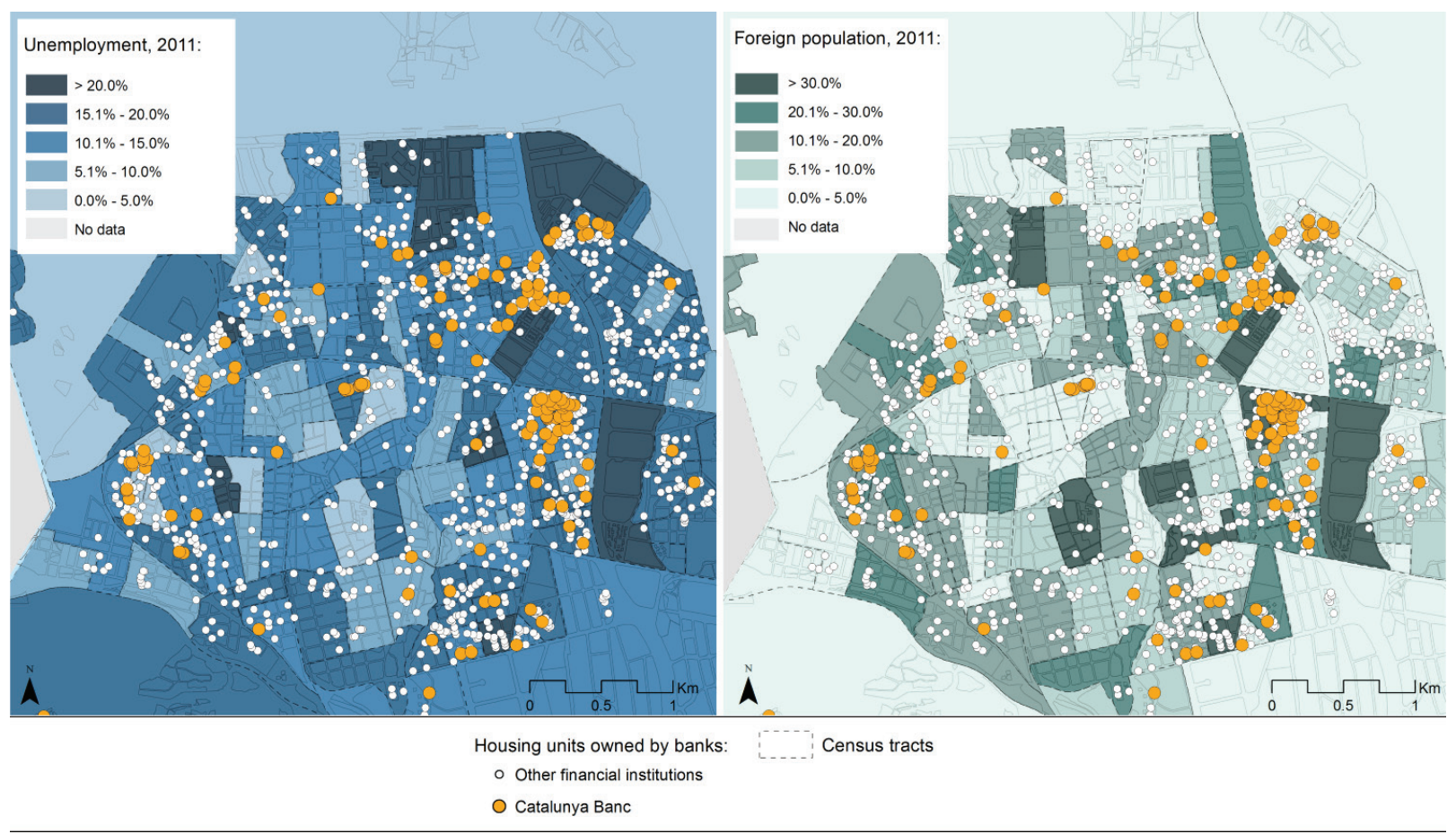

Figure 5. Housing units held by Catalunya Banc and the percentage of foreign-born population (Tarragona and Terrassa) Source: Own elaboration based on data from the 2011 census and registry of vacant housing units owned by banks in Catalonia

both cases, these are peripheral neighbourhoods with high concentrations of social housing established between 1950 and 1980 (Roquer et al. 2014). Many of these neighbourhoods have been involved in several urban regeneration programmes under the Catalan Neighbourhoods Law. This is a regional programme aiming to cofinance urban regeneration strategies in the most disadvantaged neighbourhoods of Catalan cities. This constitutes an illustrative example of their vulnerability. It can be concluded that, in both cases, the more deprived the neighbourhood, the greater was the presence of Catalunya Banc.

Surveys of evicted families taken by the PAH (Colau \& Alemany 2012) and qualitative studies undertaken by the DESC Observatory (Valiño 2015) confirmed that lower-income families were disproportionately affected by the evictions. This clearly illustrates the financial practices of Catalunya Banc and the former saving banks: they concentrated a much higher volume of mortgage credits in deprived neighbourhoods in comparison to other financial institutions (with the exception of Bankia). Furthermore, this implied taking on a higher volume of high-risk loans, a policy that is now taking its toll. Together with Bankia, Catalunya Banc is the financial institution that has produced the highest number of mortgage payment defaults and repossessions in the most deprived neighbourhoods of Catalan cities.

\section{Conclusions}

In Spain, the model of accumulation has specialized in financial investment in the secondary circuit. As a result, Spain has been one of the countries hardest hit by the economic crisis of 2008. Subsequently, under the pretext of ensuring the stability of the financial system, new forms of financial and real estate engineering have intensified the processes of accumulation by dispossession and, especially, the number of evictions due to mortgage foreclosures.
In this new financial real estate model, the financial institutions and private equity funds are the eventual benefactors. Because of the state's role as the promoter of these processes, these entities have received both direct and indirect subsidies and have seen new financial norms and frameworks created to meet their needs. As a result, private equity funds have emerged as new agents with a key role in the Spanish real estate market. This has implied an important transformation, with the primary owners of housing ceasing to be local and becoming global.

These new financial real estate mechanisms have not helped to offset either the crisis or the effects deriving from it. Moreover, they have served to increase the size of Spain's national debt and to exacerbate social vulnerability as a result of austerity policies. These strategies form part of an advance in the practice of financialization which, in the case of Spain, is currently intensifying, above all in the rental sector. This could become an important business niche and would constitute a key innovation within the Spanish real estate business. In other words, rentals could offer a new solution to the need to absorb excess capital, thereby providing a new spatial fix.

Whatever the case, the introduction of new strategies requires dispossession. This has been orchestrated through socalled policies of austerity, the socialization of losses, and the conversion of the private debt of the elite into public debt. In this sense, with these policies, the state has played a role not only in promoting forms of accumulation but also in the process of dispossession. The policies applied have left their marks on the most vulnerable neighbourhoods of our cities. It is evident that they have exacerbated vulnerability and intensified uneven development: the more vulnerable the neighbourhood, the greater the concentration of foreclosures. Furthermore, these foreclosures have been carried out by banks (like Catalunya Banc) that were previously rescued with public money. 
MISCELLANEA GEOGRAPHICA - REGIONAL STUDIES ON DEVELOPMENT

Vol. $21 \cdot$ No. 4 • 2017 • pp. 151-159 • ISSN: 2084-6118 • DOI: 10.1515/mgrsd-2017-0030

\section{Acknowledgments}

This research was funded by the Department of Research and Universities of the Catalan Government (2014 SGR 1270) and by the research projects "Crisis and vulnerability in Spain's island cities: Transformations of spaces of social reproduction"
(CSO2015-68738-P) and "New models of urban governance in the post-crisis period" (CSO 2016-75236-c2-1-r) within the National Plan for R\&D of the Ministry of Economy and Competitiveness of the Spanish Government.

\section{References}

Aalbers, M 2008, 'The financialization of home and the mortgage market crisis', Competition \& Change, vol. 12(2), pp. 148166.

Badenes, N 2015, La crisis de la Unión Europea. Causas, medidas, resultados y consecuencias políticas, económicas y socials. Instituto de Estudios Fiscales España. Available from: <http://es.slideshare.net/EUROsociALII/;la-crisisde-la-unin-europea-causas-medidas-resultados-yconsecuenciaspolticas-econmicas-y-sociales-nuriabadenes-pl-instituto-de-estudios-fiscales-espaa>. [20 May 2016].

Banco de España 2014. Available from: <http://www.bde.es/f/ webbde/GAP/Secciones/SalaPrensa/Notas/nformativas/ Briefing notes/es/notabe120614.pdf>. [12 June 2014].

Bayona, J 2007, 'La segregación residencial de la población extranjera en Barcelona: ¿una segregación fragmentada?', Scripta Nova. Revista electrónica de Geografía y Ciencias Sociales, vol. XI (235).

Bayona, J \& López-Gay, A 2011, 'Concentración, segregación y movilidad residencial de los extranjeros en Barcelona', Documents d'Anàlisi Geogràfica, vol. 57, pp. 381-412.

BOE 2014. Available from: <https://www.boe.es/boe/ dias/2014/10/08/pdfs/BOE-A-2014-10237.pdf>. [10 August 2014].

Christophers, B 2011, 'Revisiting the urbanization of capital', Annals of the Association of American Geographers, vol. 101(6), pp. 1347-1364.

Colau, A \& Alemany, A 2012, Vidas hipotecadas. De la burbuja inmobiliaria al derecho a la vivienda. Angle Editorial, Cuadrilátero Libros, Barcelona.

Coq-Huelva, D 2013, 'Urbanisation and financialisation in the context of a rescaling state: The case of Spain', Antipode, vol. 45(5), pp. 1213-1231.

El Diario 2013, Las 25 cifras de un rescate bancario sin pagar. Available from: <http://www.eldiario.es/economia/cifrasrescate-financieropagar_0_197030919.html>. [16 November 2013].

El Diario 2015, Las hipotecas de CatalunyaCaixa pasan definitivamenteamanosdeBlackstone.Availablefrom:<http:// www.eldiario.es/catalunya/hipotecas-CatalunyaCaixapasan-definitivamente-Blackstone 0 379363141.html>. [21 April 2015].

El Mundo 2013, Fracasa la subasta de Catalunya Banc por falta de interés de otros bancos. Available from: <http://www. elmundo.es/elmundo/2013/03/04/economia/1362427974. html> [4 March 2013].

El Mundo 2014, El coste del rescate de Catalunya Banc asciende a 13.000 millones. Available from: <http://www.elmundo.es/ economia/2014/07/17/53c82891e2704ebf448b456d.html>. [18 July 2014].

El País 2014, Blackstone se queda con las hipotecas tóxicas de CatalunyaBanc.Availablefrom:<http://economia.elpais.com/ economia/2014/07/16/actualidad/1405527391_807612. html>. [16 July 2014].

El País 2014, El Estado pierde unos 11.500 millones al vender Catalunya Banc al BBVA. Available from: <http://economia.elpais.com/economia/2014/07/21/ actualidad/1405965093_478597. html> [21 July 2014].
El País 2012, La banca nacionalizada traspasa al banco malo activos por valor de 37.110 millones. Available from: <http://economia.elpais.com/economia/2012/12/26/ actualidad/1356524351_995160.html> [26 December 2012].

Europa Press 2010, Caixa Catalunya, Tarragona y Manresa reciben los 1.250 millones del FROB. Available from: <http://www. europapress.es/economia/finanzas-00340/noticia-economiafinanzas-caixa-catalunya-tarragona-manresa-reciben-1250millones-frob-20100728180822.html>. [28 July 2010].

Europa Press 2014, EL FROB contempla una pérdida máxima de 531 millones en las garantías a BBVA al comprar CX. Available from: <http://www.europapress.es/economia/ finanzas-00340/noticia-economia-finanzasfrob-contemplaperdida-maxima-531-millones-garantias-bbva-comprar-cx20140722131655.html>. [22 July 2014].

García-Montalvo, J 2008, De la quimera inmobiliaria al colapso financiero. Crónica de un desenlace anunciado. Antoni Bosch Editor, Barcelona.

Gotham, KF 2009, 'Creating liquidity out of spatial fixity: The secondary circuit of capital and the subprime mortgage crisis', International Journal of Urban and Regional Research, vol. 33(2), pp. 355-371.

Gutiérrez, A \& Delclòs, X 2015, ‘ ¿Hipertrofia inmobiliaria? Análisis de las pautas territoriales del boom e implicaciones del estallido de la burbuja en Cataluña. Cuadernos Geográficos, vol. 54(1), pp. 283-306.

Gutiérrez, A \& Delclòs, X 2016, 'The uneven distribution of evictions as new evidence of urban inequality: A spatial analysis approach in two Catalan cities', Cities, vol. 56, pp. 101-108.

Gutiérrez, A \& Delclòs, X 2017, 'Geografía de la crisis inmobiliaria en Cataluña: Una lectura a partir de los desahucios. Scripta Nova. Revista Electrónica de Geografía y Ciencias Sociales, vol. XXI(57)

Gutiérrez, A \& Domènech, A 2017a, 'The Spanish mortgage crisis: Evidence of the concentration of foreclosures in the most deprived neighbourhoods', Die Erde - Journal of the Geographical Society of Berlin, vol. 148(1), pp. 39-57.

Gutiérrez, A\& Domènech, A. 2017b, 'Geografía de los desahucios por ejecución hipotecaria en las ciudades españolas: evidencias a partir de las viviendas propiedad de la SAREB. Revista de Geografía Norte Grande, vol. 67, pp. 33-52.

Harvey, D 2003. The New Imperialism, Oxford University Press, Oxford.

Lapavitsas, C 2012, Crisis en la Eurozone. Capitán Swing Libros, Madrid.

Lne 2012, El FROB se queda con el $100 \%$ de Catalunya Banc por un euro. Available from: <http://www.Ine.es/ economia/2012/12/17/frob-queda-100-catalunyabanceuro/1342755.html>. [17 December 2012].

López, I \& Rodríguez, E (eds.) 2010, Fin de ciclo. Financiarización, territorio y sociedad de propietarios en la onda larga del capitalismo Hispano (1959-2010). Traficantes de sueños, Madrid.

López, I \& Rodríguez, E 2011, 'The Spanish model', New Left Review, vol. 69, pp. 5-28.

López, I \& Rodríguez, E 2013, 'Competitividad territorial y circuito secundario de acumulación. El paroxismo de un caso: el ciclo 
español de 1995-2007. In Paisajes devastados. Después del ciclo inmobiliario: impactos regionales y urbanos de la crisis, eds. I López \& E Rodríguez, Traficantes de sueños, Madrid, pp. 25-75.

Martori, JC \& Hoberg, K 2008, 'Nuevas técnicas de estadística espacial para la detección de clusters residenciales de población inmigrante', Scripta Nova. Revista electrónica de Geografía y Ciencias Sociales, vol. XII(263).

Plataforma Auditoría Ciudadana de la Deuda 2013, La ilegitimidad de los Rescates a la Banca en el Estado español. Available from: <http://auditoriaciudadana.net/documents/>. [20 May 2016].

Pujol-Perdices, M \& Gutiérrez, A 2017, 'Segregación residencial de la población extranjera en un destino turístico maduro: el caso de La Pineda (Costa Dorada)', Lurralde: invesestigación y espacio, vol. 40, pp. 167-192.

Rodríguez García, R 2013, 'La reforma financiera y la reestructuración del sector español de bancos y cajas de ahorro [Financial Reform and the restructuring of Spanish banks and savings banks sector]', Icade. Revista cuatrimestral de las Facultades de Derecho y Ciencias Económicas y Empresariales, vol. 89, pp. 11-31.

Roquer, S, Gutiérrez, A, Muro, JI \& Alberich, J 2014, 'La regeneración integral de barrios en Cataluña mediante la "Llei de Barris": análisis comparado y valoración de los casos de "La Mariola" (Lleida) y Campclar (Tarragona)', Polígonos. Revista de Geografía, vol. 25, pp. 277-309.
Ruiz, JR, Stupariu, P \& Vilariño, A 2016, 'The crisis of Spanish savings banks', Cambridge Journal of Economics, vol. 40 (6), pp. 1455-1477.

Rutland, T 2010, 'The financialization of urban redevelopment', Geography Compass, vol. 4, (8), pp. 1167-1178.

Sánchez Mato, C 2013, Por una banca pública. [For a public bank]. Available from: <http://matoeconomia.blogspot.com. es>. [20 May 2016].

Sevilla-Buitrago, A 2015, Urbanismo, crisis y austeridad. Ciudades, vol. 18, pp. 31-48.

Smith, N 1984 [2010], Uneven Development: Nature, Capital and the Production of Space. Verso, London.

Valiño, V (ed) 2015, Emergència habitacional a Catalunya. Impacte de la crisi hipotecària en el dret a la salut i els drets dels infants. Observatorio DESC y Plataforma de Afectados por la Hipoteca, Barcelona.

Vives-Miró, S 2015 'Private Equity Firms in the Spanish property market', Researching Transnational Landlords, 20-22 July, 2015. London 